\title{
POLA REHABILITASI ISLAMI BAGI PECANDU NARKOBA DI BADAN NARKOTIKA NASIONNAL PROVINSI RIAU: PERSPEKTIF KONSELING ISLAM
}

\author{
Zulamri \\ Dosen Fakultas dakwah dan komunikasi UIN Suska Riau, \\ Jl. HR. Soebrantas Km 15 Simpang Baru, Tampan, Pekanbaru 28293 \\ Email :zulamri@uin-suska.ac.id
}

\begin{abstract}
Abstrak
Kesesuaian pola rehabilitasi dan teknik yang diberikan pada pasien harus memiliki kesesuaian dengan kondisi pasien yang diantaranya adalah faktor kultur tempat individu berkembang, namun dalam konteks penerapannya di Indonesia yang mayoritas penduduknya Islam. Pada dasarnya proses dan teknik rehabilitasi Islam ada tiga tahap yaitu tahap pembersihan diri, pengembangan diri, dan penyempurnaan diri, ketrampilan dan keahlian tidak akan datang dan bertambah dengan sendirinya tanpa adanya suatu latihan-latihan. Napza, yang merupakan singkatan dari Narkotika,Psikotropika dan Zat Adiktif merupakan jenis bendayang menjadikan orang yang mengkonsumsunya mabuk, sehingga merusak akal dan psikis serta organ-organ tubuh lain. Penelitian ini dilakukan di Badan Narkotika Nasional (BNNP) Provinsi Riau yang responden penelitian ini adalah pengelola dan konselor dengan cara memperoleh langsung data dari responden melalui informasi dari wawancara dan kuesioner yang dilakukan serta dokumentasi. Analisis data menggunakan metode deskriptif, yaitu menguraikan fakta yang diperoleh kemudian dihubungkan dengan teori yang ada dan diinterpretasikan untuk memperoleh makna dan implikasi hubungan yang ada. Hasil dari penelitian ini yaitu pola rehabilitasi islam pencandu narkoba di BNNP Provinsi Riau perspektif islam merupakan bagian integral dalam program pemulihan bagi residen di BNNP Provinsi Riau. Dalam proses pola rehabilitasi kebanyakan residen tidak bisa diharapkan untuk menyelesaikan masalahnya sendiri. Sehingga diperlukan suatu upaya bantuan guna membantu residen dalam proses pemulihannya, yaitu salah satunya dengan menanamkan nilai-nilai islami di dalam diri pecandu narkoba.
\end{abstract}

Kata Kunci: Rehabilitasi, napza, implikasi, residen.

\section{A. Pendahuluan}

Kehidupan manusia di dunia ini telah di takdirkan allah SWT sebgai wadah menjalani ujian darinya. Semua waktu yang di habiskan dann semua aktifitas yang dilakukan adlah dalam rangka menjalani ujian dari-nya. Ujian bukan hanya bersifat sesuatu yang beratkan jiwa dan raga manusia, tetapi juga merupakan kelebihan rezki. Ujian berupa kelebihan rezki adalah untuk membuktikan apakah orang yang di beri rezki itu mampu bersyukur atau tidak, sedangkan ujian dalam bentuk kesusahan atau musibah adlah menguji kesabaran. Sebagaimana firman allah dalam surat al-mulk :2Artinya : yang menjadikan mati dan hidup, supaya Dia menguji kamu siapa di antara kamu yang lebih baik amalnya. Dan Dia Maha Perkasa lagi Maha Pengampu."

Narkoba adalah singkatan dari narkotika dan obat-obatan terlarang. Selain dari narkoba, istilah lain yang dipekenalkan oleh Menteri Kesehatan Indonesia untuk menyebut benda ini adalah napza, ysng merupakan singkatan dari narkotika, psikotropika dan zat adiktif. ${ }^{1}$ Benda-benda tersebut menjadikan orang yang mengkonsumsunya mabuk, sehingga merusak akal dan organ-organ tubuh lain sehingga

\footnotetext{
${ }^{1}$ Wikipedia Bahasa Indonesia, lihat http://id.wikipedia.org/wiki/Narkoba
} 
islam sangat mengharamkan perkara ini serta pelakunya dikategorikan kepada pelaku dosa besar dan bahkan oleh para ulama menyatakan bahwa mabuk-mabukan itu adalah ra'su alma'ashi (induk dari segala maksiatan). Dalam Islam semua benda-benda yang memabukkan itu disebut khamar.

Tidak dipungkiri bahaya negatif narkoba secara langsung terhadapa kesehatan sangat besar, merusak otak dan menimbulkan penyakit fisik lainnya serta bahkan banyak yang mengakibatkan kematian. Hal ini jika tidak diantisipasi secara maksimal oleh semua pihak maka akan mengancam masa depan bangsa dan Negara. Para pecandu sangat sulit untuk melepaskan diri dari jeratan narkoba kecuali dengan usaha yang gigih dari berbagai pihak, baik pelaku sendiri ataupun pihak keluarga, lingkungan, pemerintah dan lembaga-lembaga yang secara khusus menangani rehabilitasi pecandu narkoba. Biaya dan pengorbanan yang dibutuhkan juga tidak sedikit.

Di indonesia, terdapat lembaga-lembaga yang khusus menangani rehabilitasi atau pemulihan para pecandu narkoba. Metode pemulihan yang di pergunakan secara umum ada dua bentuk, yaitu, pertama, metode islami dengan pendekatan pemulihan sesuai ajaran islam- walaupun secara konkirit cara seperti ini pada masa Rasul SAW. tidak di pergunakan untuk menangani pecandu narkoba - seperti mandi, wudhu, shalat zikir dan ibadah-ibadah lainnya. Metode seperti ini tidak mempergunakan obat-obatan media yang biasa dipakai dokter untuk menenangkan para pecandu. kedua $^{2}$, metode pemulihan medis yang mempergunakan obat-obatan medis seperti obat psikotik, obat anti nyeri, obat anti depresi, dan lain-lain kedua metode rehabilitasi atau pemulihan ini sangat berbeda satu sama lain.

\section{B. Pandangan islam tentang pengguna narkoba}

Dalam islam narkoba termasuk dalam kategori khamar, sebab zat yang merusak akal yang disebut narkoba belum ada pada masa rasulullah SAW. dan semua benda yang memabukkan serta merusak akal merupakan

\footnotetext{
${ }^{2}$ Lihat http://madanionline.org/program-stabilisasimadani-metode-prof-dr-dr-h-dadang-hawaripsikiater/
}

bagian dari khamar. Sebab kata "khamar" sendiri bermakna sesuatu yang menutup akal.

Keharaman khamar disebutkan dalam Al-Quran dan sunnah rasulullah SAW >Allah SWT berfirman dalam surat al-Maidah :90 Artinya : Wahai orang-orang beriman, sesungguhnya ( meminum) khamar, berjudi, (berkoban untuk) berhala, mengundi nasib dengan panah, adalah termasuk perbuatan syaithan. Maka jauhilah perbuatan-perbuatan itu agar kamu mendapat keberuntungan.(alMaidah:90)

Ayat ini menyebutkan empat perkara yang dilarang sebagai najis, yaitu khamar, berjudi, berkorban untuk berhala, dan mengundi nasib, yang mana larangan dengan menyebut sebagai najis menunjukkan larangan tertinggi. Tingkatan larangan khamar dalam ayat ini disamakan dengan larangan berbuat syirik dengan cara berkorban untuk berhala. Hal ini menandakan kerusakan yang ditimbulakan oleh khamar sangat besar, bukan hanya merusak pribadi tetapi dapat merusak generasi muda dan bangsa.

Disamping kitab tafsir, khamar juga dibicarakan dalam kitab syarah hadis, seperti kitab fath al-bari yang merupakan syarah kitab sahih al-bukhari yang ditulis oleh ibnu hajar al-atsqalani, kitab 'Aunul Ma'bud syarah kitab sunan Abi Daud ketika menjelaskan maksud hadis " segala yang memabukkan adalah khamar", menyebutkan pendapat akl-khattabiy bahwa ungkapan ini ditakwilkan dua segi yaitu ${ }^{3}$

1. Khamar adalah kata untuk menyebut semua jenis minuman yang memabukkan. Pendapat ini menyatakan bahwa islam memasukkan nama minuman apa saja yang memabukkan kedalam khamar walaupun belum ada pada masa Rasulullah SAW.

2. Semua benda yang memabukkan disamakan hukumnya dengan hukuman peminum khamar walaupun zatnya bukan khamar yang ada pada masa Nabi SAW sebagimana halnya hukuman pelaku homoseksual dengan pezina.

\footnotetext{
${ }^{3}$ Abu al-thayyib muhammad syams al-haq al-'azim al-abadiy,'aun al-ma'bud syarh sunan abi daud, (madinah al-munawwarah: al-maktabah al-slafiyah, 1968), juz 9, h. 573
} 
Pembahasan tentang khamar dan hukuman bagi pelakunya, disamping dikaji dalam kitab tafsir dan syarah hadis juga terdapat dalam kitab-kitab fiqh, seperti kitab fiqh mazhab yang ke empat, yaitu Mazhab mengkaji perkara khamar ini, mereka berbeda pendapat tentang hukuman bagi orang yang mabuk.

Kajian tentang khamar dan hukuman yang mesti diterapkan kepada pelaku bukannya hanya terdapat dalam kitab tafsir AlQuran, syarah-syarah Al-Sunnah, ijitihad para ulama mazhab fiqh, tetapi juga dibahas oleh ulama-ulama besar lainnya seperti Ibnu Taimiyah dalam kitabnya Mjmu' al-Fatawa, Ibnu Qayyim dan lain-lain.

Menurut penulis, had atau hukuman dunia terhadap peminum khamar atau pemabuk yang telah ditetapkan oleh rasulullah dalam hadisnya merupakan salah satu langkah terapi rehabilitasi pecandu narkoba. Artinya dengan melakukan hukuman cambuk, para pelaku telah dibimbing kepada kesadaran untuk mengembalikan dirinya kepada keadaan semula, sehat dari kerusakan akal, hilang dari ketergantungan terhadap khamar, namun proses berikutnya mesti dilanjutkan dengan menjalankan sunnah-sunnah Beliau yang lain.

\section{Kajian tentang narkoba dan mote pemulihan pecandu narkoba oleh ilmuan kontemporer}

Buku - buku yang mengkaji tentang narkoba dan metode pemulihan para pecandu sudah banyak ditulis oleh penulis-penulis kontemporer, di antaranya:

1. Buku "Rehabilitasi bagi korban Narkoba yang ditulis oleh Tim Visi Media tahun terbit 2006. Dalam buku ini, Tim Visi Media memaparkan langkah-langkah rehabilitasi pecandu narkoba secara media.

2. Buku "Al-quran ilmu kedukteron jiwa dan kesehatan jiwa", Buku ini ditulis oleh dadang hawari, seorang psikiater yang banyak menulis tentang kejiwaan dan bagaimana penangannan korban-korban narkoba. dalam buku ini, Beliau menulis konsep-konsep kedokteran dan kesehatan jiwa dari ayat-ayat Al-Quran dan hadishadis Nabi SAW. Buku ini diterbitkan pada tahun 2012 oleh penerbit Madani Press. Dalam buku ini dikupas berbagai permasalahan kehidupan manusia: Khususnya yang menyangkut kesejahteraan hidup dari sudut pandang ilmu kedokteran jiwa (psikiatri) dan kesehatan jiwa dengan merujuk pada $\mathrm{Al}$ Qur'an dan Al Hadits. Atas dasar AlQur'an dan Al Hadits itulah, pemasalahan kehidupan manusia dizaman modern ini seperti stres, kecemasan, depresi, eksistensi rumah tanggga, naza (Narkotika, Alkohol \& Zat Adiktif), HIV/AIDS, MAU-LIMO (Madat, Minum,Main,Maling dan Madon) dan lain sebaginya, dikaji dua pendekatan yaitu pendekatan ilmu pengetahuan di satu pihak dan agama di lain pihak, antara keduanya terdapat titik temu.

3. Buku "Lima Besar Penyakit Mentak Masyarakat", ditulis oleh Dadang Hawari dan diterbitkan tahun 2012 oleh Madani Press. Dalam buku ini diuraikan lima besar penyakit mental masyarakat yang merupakan pertanda SDM tidak berkualitas. Penyakit tersebut dikenal dengan istilah mau-LImo yang merupakan singkatan dari maling( korupsi), madon (perzinaan), Main (berjudi), Minum (miras/alkohol), dan madat (narkoba)

4. Buku "Mencegah Bahaya Penyalahgunaan Narkoba Melalui Pendidikan Budaya Dan Karakter Bangsa, SMA/MA/SMK." buku ini ditulis oleh Suyadi diterbitkan oleh Andi Publisher. Buku ini merupakan upaya mencegahan bahaya penyalahgunaan narkoba melalui pengembangan pendidikan budaya dan karakter bangsa. Landasan yuridis buku ini adalah nota kesepakatan atau MOU antara kemandigbud dan BNN pada

\section{Metode penelitian}

\section{A. Desain penelitian}


Penelitian ini termasuk dalam jenis penelitian kualitatif, yaitu model penelitian dengan mengutamakan bahan-bahan yang sukar diukur dengan angka-angka atau dengan ukuran - ukuran lainnya yang brsifat eksak, walaupun bahan- bahan tersebut terdapat dengan nyata di dalam masyarakat. Penelitian kualitatif merupakan jenis penelitian yang temuan-temuannya tidak diperoleh melalui prosedur statistik atau bentuk hitungan lainnya, seperti tentang kehidupan, perilaku seseorang, peranan organisasi, pergerakan sosial dapat di hitung sebagaimana data sensus, namun analisanya bersifat kualitatif. Penelitian ini cocok dalam penelitian kualitatif yang bersifat dari masalah yang diteliti, yaitu yang berhungan dengan prilaku seseorang atau studi kasus. Metode kualitatif dapat digunakan untuk mengungkapkan dan memahami sesuatu di balik fenomena yang belum diketahui.

Selain itu, penelitian itu juga termasuk dalam jenis penelitian dengan metode deskriptif. Penelitian deskriptif adalah suatu metode dalam meneliti status kelompok manusia, suatu objek, suatu kondisi, suatu sistem pemikiran atau suatu kelas peristiwa pada masa sekaran.

\section{B. Lokasi penelitian}

Penelitian ini dilakukan di badan narkotika nasional provinsi riau pola rehabilitasi islami bagi pecandu narkoba dibadan narkotika nasional provinsi riau.

\section{Responden penelitian}

Responden penelitian ini adalah pengelola di badan narkotika nasional provinsi riau pola rehabilitasi islami bagi pecandu narkoba di badan narkotika nasional provinsi riau.

\section{Sumber data}

Data yang akan dikumpulkan dan diperoleh dalam penelitian ini dapat di kelompokkan kepada :

1. Data primer : data yang diperoleh langsung dari responden melalui informasi dari wawancara dan kuesioner yang dilakukan.

2. Data sekunder : data yang diperoleh melalui dokumentasi atau sumber lainnya untuk menunjang objek yang di teliti.

\section{E. Teknik pengumpulan data}

Data yang dalam penelitian ini diperoleh dengan menggunakan teknik pengumpulan data yaitu :

a. Observasi : dilakukan dengan cara datang dan mengamati secara langsung kegiatan rehabilitasi.

b. Wawancara : melakukan tanya jawab secara langsung dengan responden sesuai dengan daftar pertanyaan yang telah disusun sebelumnya untuk memperoleh data tentang kegiatan rehabilitasi.

c. Studi dokumentasi : dilakukan untuk memperoleh data tentang kegiatan rehabilitasi.

\section{F. Analisis data}

Setelah data-data diperoleh, kemudian data dikelompokkan berdasarkan jenis dan sumbernya, penganalisaan data menggunakan metode deskriptif, yaitu menguraikan fakta yang diperoleh kemudian dihubungkan dengan teori yang ada.

Data yang telah terkumpul dianalisis setiap waktu secara induktif selama penelitian berlangsung dengan mengolah bahan empirik, supaya dapat disederhanakan ke dalam bentuk yang lebih mudah dibaca, dipahami dan diinterpretasikan. Data diinterpretasikan untuk memperoleh makna dan implikasi hubungan yang ada. Data ini di rangkum secara deskriptif untuk membantu menemukan konsep-konsep keaslian yang di ungkapkan oleh subjek penelitian sendiri sesuai dengan kenyataannya. Dengan cara ini tetap akan dapat menyajikan realitas senyatanya ( emik) sebagimana yang di harapkan dalam penelitian kualitatif

\section{Hasil penelitian dan pembahasan}

Proses rehabilitasi korban penyalahgunaan korban merupakan upaya kesehatan yang dilakukan secara utuhh dan terpadu melalui pendekatan non medis, psikologid, sosial dan religi agar pengguna narkoba yang menderita sindroma ketergantungan dapat mencapai kemampuan 
fungsional seoptimal mungkin. Dalam mencapai tujuan dari proses tersebut di butuhkan suatu layanan bantuan berupa konseling. Hal ini di dasari bahwa tidak semua klien yang mengikuti program rehabilitasi memiliki masalah yang sama (walaupun samasama pengguna). Adanya konseling tersebut tentunya memiliki beberapa tujuan yang hendak di capai, langkah- langkah dalam proses konseling,dan pendekatan konseling yang digunakan.

Jenis penelitian yang penulis gunakan dalam penelitian ini adalah penelitian kualitatif dengan pendekatan deskriptif sebagai prosedur penelitian yang akan menghasilakan data deskriptif berupa kata-kata tertulis dan lisan dari informan baik individu atau kelompok. Penelitian ini merrupakan penelitian lapangan, maka data yang penulis butuhkan adalah data primer, yaitu data yangdiperoleh langsung dari lapangan. Subyek penelitian merupakan semua orang yang menjadi sumber atau informan yang dapat memberikan keterangan mengenai masalah penelitian.

Untuk memperoleh informasi mengenai gambaran umum lembaga dan proses rehabilitasi korban yang dilaksanakan di BNNP Provinsi Riau, penulis melakukan pencarian informasi kepada manager program yaitu kepada dr. herlina. Obyek penelitian ini yang menjadi obyek penelitian adalah pola rehabilitasi islam pecandu narkoba di BNNP Provinsi Riau pespektif konseling islam. Konseling yang mencakup tujuan, proses dan pendekatannya dalam proses rehabilitasi korban narkoba yang dilaksanakan di BNNP Provinsi Riau.

Metode pengumpulan data dalah wawancara adalah pengamatan informasi dengan cara mengajukan sejumlah pertanyaan secara lisan untuk di jawab secara lisan pula. Ciri utama dari wawancara atau interview adalah kontak langsung dengan tatap muka antara inteviewer dan sumber informasi. Sehubungan dengan obyek penelitian ini, maka penulis mengadakan wawancara secara perorangan yaitu kepada 4 (empat) orang pegawai di BNNP Provinsi Riau dan manager program. Metode wawancara yang penulis gunakan dalam penelitian ini adalah wawancara secara langsung, beupa wawancara secara mendalam terhadap informan/subyek penelitian. Observasi/pengamatan dan dokumentasi

Penulis memperoleh keabsahan data, penulis menggunakan teknik triangulasi. Teknik triangulasi adalah tehnik pemeriksaan data yang memanfaatkan sesuatu yang lain di luar data itu untuk keperluan mengecekan atau sebagai pembandi terhadap data tersebut.

Hasil dari penelitian ini yaitu pola rehabilitasi islam pencandu narkoba di BNNP Provinsi Riau perspektif islam merupakan bagian integral dalam program pemulihan bagi residen di BNNP Provinsi Riau. Dalam proses pola rehabilitasi kebanyakan residen tidak bisa diharapkan untuk menyelesaikan masalahnya sendiri. Sehingga diperlukan suatu upaya bantuan guna membantu residen dalam proses pemulihannya, yaitu salah satunya dengan konseling

Hal ini dapat dilihat dari tujuan konseling yang sejalan dengan upaya rehabilitasi terutama mengarah pada aspek psikologis dan sosial. Proses konseling juga disediakan sesuai dengan kebutuhan residen selama mengikuti rehabilitasi sehingga mempermudah residen dalam menyapaikan masalah yang dialaminya kepada konselor setiap saat. Sedangkan pada pendekatan konseling yang digunakan adalah konseling RET dan konseling realitas.

Berdasarkan data prevalenssi penyalahguna narkoba di Indonesia teralah mencapai $1,99 \%$ dari total populasi penduduk atau sekitar 3,6 juta jiwa. Delapan puluh enam persen penyalahguna narkoba berada pada usia produktif.upaya penanggulangan penyalahgunaan narkoba besifat komprehensif. Bagi pecandu atau penyalahguna, undangundang telah memberikan hak-hak bagi mereka untuk mendapatkan rehabilitasi medis dan sosial. Saat ini badan narkotika nasional memiliki sebuah panti rehabilitasi berkapasitas 500 residen atau pecandu yang terletak di lido bogor.

\section{Kesimpulan dan saran}

Hasil penelitian ini yaitu pola rehabilitasi islam pecandu narkoba di BNNP provinsi riau persepektif islam merupakan bagian integral 
dalam program pemulihan bagi residen di BNNP provinsi riau. Dalam proses pola rehabilitasi banyak residen tidak bisa diharapkan untuk menyelesaikan masalahnya sendiri dan mereka tidak mengetahui kelemahan dan kekuatan atau kelebihan mereka sendiri. Sehingga diperlukanlah suatu upaya bantuan guna membantu residen dalam proses pemulihannya, yaitu salah satunya dengan konseling.

Hal ini dapat dilihat dari tujuan konseling yang sejalan dengan upaya rehabilitasi terutama mengarahkan pada aspek psikoloagis dan sosial dalam tinjauan islam.

\section{Saran}

Diharapkan pihak BNNP Riau lebih dan fokus penerapan metode teraphy bagi pecandu narkoba dengan menghadirkan den mengikuti sertakan dari konselor islam dan bagi peneliti selanjutnya diharapkan melakukan penelitian model konseling islami yang lebih sesuaian dengan pemulihan dan terapi bagi pecandu narkoba.

\section{Daftar kepustakaan}

Abdullah,Ahmad Norma Permata (ed), Amin. Metodologi Studi Agama, Yogyakarta: Pustaka Pelajar,2000

Arikunto,Ny. Suharsimi,Prosedu

Penelitian:Suatu

Pendekatan

Praktek,Rinnela

Cipta,Jakarta,2009.
Abu Zaid,Bakr ibn AbdIllah Muhammad. Hajra 1- Mubtadi',Riadh :Maktabah alSalaf,tt Bukhari ,Abu Abdullah Muhammad bin Isma'il al Shaheh al-Bukhori, Dar alFikr,Beirut, tt, Juz Depag RI,Tim Penterjemah. Al- qur'an dan Tejemahanya, Makkah alMukaramah: Khadim al-Haramayn, 1991

Ibnu Manzhur al- Anzhari al-Ifriqi, Muhammad bin Mukrim bin Ali Abu Fadhal Jamaludin. Lisan al-Arab, Beirut: Dar al-Fikr,tt.

Maman, dkk., U. Metodologi Penelitian Agama ; Teori dan Praktek, Jakarta : PT. Rajawali Press, 2004.

Maleong ,Lexy J. Metodologi Penelitian Kualitati, Bandung ; PT. Remaja Rosdakarya, 1997

Nazir , Mohd. Metode Penelitian, Jakarta : Bina Aksara, 2000

Naisbury, Abu al-Husayn bin alHajjaj al- Qushairiy Muslim alShaheh Muslim Dar al-Fikr,Beirut, tt,Juz I.

Robbins dan Timmothy judge, stepen P, Organizational Behavior ( Prilaku Organisasi), Terjemahan Diana Angelica, Bandung : PT. Remaja Rosdakarya, 2008.

Soekanto, Soerjono. Kamus Sosiologi, Jakarta: Royandi,1985.

Patton,Michael Quin. Qualitative Evolotion and Reasearch Methode, Newbury Park : SagePublication,1990 